\title{
New Human Resource Management Systems in Non-Based-Knowledge Firms: Applications for Decision Making on the Business Performance
}

\author{
Pilar Ficapal-Cusí, Joan Torrent-Sellens \\ Economics and Business Studies, Open University of Catalonia (UOC), Avinguda Tibidabo, Barcelona, Spain \\ Email:pficapal@uoc.edu, jtorrent@uoc.edu
}

Received December 5, 2013; revised February 5, 2014; accepted February 12, 2014

Copyright (C) 2014 Pilar Ficapal-Cusí, Joan Torrent-Sellens. This is an open access article distributed under the Creative Commons Attribution License, which permits unrestricted use, distribution, and reproduction in any medium, provided the original work is properly cited. In accordance of the Creative Commons Attribution License all Copyrights (C) 2014 are reserved for SCIRP and the owner of the intellectual property Pilar Ficapal-Cusí, Joan Torrent-Sellens. All Copyright @ 2014 are guarded by law and by SCIRP as a guardian.

\section{ABSTRACT}

The aim of this paper is double. First, it provides a conceptual framework and modelling of the relationship between human resource management (HRM) systems and non-based-knowledge firms. Second, using survey data on 1.518 Catalan firms (in Spain, with capital in Barcelona), the paper: 1) identify two system of HRM (in progress HRM system and non-HRM developed system); 2) build a causal model of determinants of HRM systems; and 3) describe the association links between in progress HRM system and firm's performance. Using factor and cluster analysis, we find that only one-third of firms use in progress HRM system. Using logit binomial analysis, we find that features which are structural, technological, strategic, organisational and performance-related explain the adoption of in progress HRM system. Finally, using association analysis, we find that firms that adopt in progress HRM system: 1) are more internationalised and show greater ability to adapt to the changing environment, to innovate and to collaborate; 2) focus on product/service differentiation strategy enhancing quality; 3 ) apply a greater degree of new forms of work organization; 4) have more technological equipment and use IT more intensively; and 5) invest more in training their employees, than firms with non-HRM system developed.

\section{KEYWORDS}

Human Resource Management (HRM) Systems; Non-Based-Knolwedge Firms; Firms Performance; IT Use; Work Organization

\section{Introduction}

In the transition process towards a global knowledgebased economy, characterised, among other features, by the interaction between information technologies (IT), new forms of work organisation, knowledge management, new competence needs and the reformulation of labour relations, human resources management (HRM) is shaping up as a determining element in the firms' competitiveness [1-6]. Since the mid 90's, the consolidation and productive use of IT, improved HRM, especially e-HRM [7-9], and organisational redesign have developed in parallel, and together require workers who are better trained and more highly motivated $[10,11]$. Although the nature of this relationship is complex, it has been demonstrated that the delegation of responsibility and decreased hierarchical levels, together with: 1) intensive use of IT and the flow of information and knowledge; and 2) HRM which increases workers' commitment, ultimately promoting business process innovation [12,13] and improving the firm's productivity and competitiveness [14-17].

Thus, considering the symbiotic relationship between IT, organisational change and new HRM practices, this paper will analyse HRM systems for the specific case of the Catalan firm. The data obtained from a representative sample of 1518 companies from Catalonia (Spanish region, whose capital is Barcelona) are extremely useful, firstly, due to the fact that we can compare the degree to which HRM systems are implemented throughout an entire productive network, with all types of private pro- 
ductive activities and very heterogeneous practices of human capital management; secondly, because the results obtained can, to a great extent, be extrapolated. The overall productive network in Catalonia has certain specific features, with smaller-sized companies, low intensively use of technology and knowledge, low innovation performance, low level of job training, a deficient level of IT use, and serious problems of efficiency and competitiveness [18]. This non-based-knowledge firm's feature is also the situation in other world regions; therefore the results obtained from this analysis may be valid to describe the sources of competitive advantage related to HRM in other areas or business groups.

The aim of this paper is double. Theoretically, it provides a conceptual framework and modelling of the relationship between human resource management (HRM) systems and non-based-knowledge firms. Empirically, it is to find which types of HRM systems can be adopted by Catalan firms and to establish their determinants. The empirical examination is as follows. Firstly, we describe the data of several HRM practices. We will contrast the empirical evidence that HRM practices should be adopted in clusters (systems) given the existence of complementarities among these practices. Secondly, we establish a typology of two HRM systems (in progress HRM system and non-HRM developed system) for the specific case of our subject of study. Thirdly, we develop the causal model for the adoption of in progress HRM system. It will allow us to provide a richer interpretation of the factors that firms use to shape part of their competitive advantage. Finally, we analyse the characteristics of the firms that adopt in progress HRM system, and summarize results that make a link between dimensions of business performance and system of in progress HRM.

\section{Conceptual Model and Research Hypotheses}

This section summarises the body of research pertaining to HRM and the relationships of interdependence between certain internal and external firm components. Testable hypotheses are also presented. Additional explanatory variables and empirical issues are discussed in the next sections.

The term HRM practices is defined as the pattern of planned human resource deployment and activities that help organisations attract, evaluate, motivate, and develop people with the appropriate behaviours and competencies to meet current and future needs [19].

Since the beginning of the 90's, literature on HRM provides us with a noteworthy body of empirical evidence centring on the appearance of innovative HRM practices and their effects on the organisation's results [20-22]. This empirical evidence suggests that firms able to transform their workers' basic competences, flexibly organise production and labour, and establish labour relations that increase the commitment of the workforce, have a greater competitive advantage at their disposal than do those firms with more traditional HRM [23-26].

New HRM practices are often referred to as high involvement or high performance work system [23]. The literature has identified a set of HRM practices in various ways that would assure the adoption of flexible work systems [21,27], but generally they include three dimensions that are related to: 1) skills and competency requirements; 2) developmental approach to enhance continuous learning and performance as well as; and 3) innovative remuneration and labour relations programmes based on performance-related pay that drive motivation and commitment $[19,28]$.

Within this context, we will begin with the premise that the results of an innovativeness HRM system do not depend, solely, on how each of the practices is managed separately. The final result also depends on how these practices interact with one other. There is no doubt that having more qualified workers who have been selected with greater care, and who work in a system that allows and encourages them to use their skills provides higher levels of organisational performance [29]. As the empirical literature shows, organisations gains from the internal consistency of their HRM, obtained through the suitable coordination between the different management practices and the high involvement of the workers [28] [30,31].

Following this line, and based on what is extracted from the various studies, we propose to analyse HRM practices based on the following four dimensions, considered to be important driving forces for organisational performance [29]:

1) Selective hiring. The selection processes should be based on the ability of the employees to do their job. The workforce should be recruited with the necessary knowledge, skills and abilities to deliver organizational objectives and to contribute positively to the aims of the firm. Moreover, a great deal of research suggests that the degree of cultural values congruence between job applicants and their organizations significantly predict job performance. We will infer the hiring requirements firms set on the basis of educational level and the perception of managers on the most important abilities and values.

2) Investment in training. We refer to the HRM practices dedicated to improving the workforce's level of training. We will deal with the degree to which firms provide extensive training, in terms of the number of employees involved.

3) Remuneration practices. Contingent compensation figures as being important in most high-performance work systems. The different tools for variable remuneration have been established as mechanisms for flexibility 
in salary and are explicitly designed to assign economic compensation based on the achievement of certain objectives or results. Thus, different forms of remuneration have been analysed. Remuneration packages include a balance between a fixed-based component and an incentive-based component being based upon the performance evaluation system. We have also obtained information relating to the average salary and salary structure.

4) Employment security. Lastly, we will analyse the labour relations system existing in Catalan companies. We are specifically interested in the labour relations established pursuant to a job contract with a permanent or temporary nature.

Revision of the available empirical evidence confirms the existence of important relationships of interdependence between certain internal and external aspects of structure of firms and the intensity with which innovative HRM systems are adopted [15]. As these practices become more sophisticated, they progressively form part of an overall system which, in turn, interrelates with other relevant aspects of business activity. One of the first relationships that the literature contrasts is the link between innovative HRM practices and business strategy; specifically with: a) business strategy of differentiation; and b) a stable collaborative strategy with knowledge institutions.

From a technological perspective, it has been demonstrated that digital investment is greater in those firms which delegate decision-making to their employees, more is invested in skills training, and organisational structures that are less vertical are adopted [32]. Within this context, the complementary nature between innovative HRM practices and IT use determines: 1) an important increase in the competences required from the workforce [33,34]; and 2) if combined with reorganisation of the organisational architecture, ultimately, an improvement of the firm's productivity [35-40] as are the workers' salaries [41-44].

Thus, and based on the four elements which define the dimension of HRM in an organisation and their growing complementary relationships with other characteristics of firms, we will then conceptualise and measure these innovative system. By in progress HRM system we mean that group of practices which, acting as a complete system, is characterised by: 1) a higher level of competence of their employees; 2) the effort made in selecting and training them; 3) a set of practices related to the transfer of power; 4) the quality of labour relations; and 5) remuneration which is managed through a system of setting objectives and performance review. Constructing an indicator for in progress HRM system must allow us to: 1) provide an indicator for a system of new HRM practices; 2) describe the extension of these practices in the non-based-knowledge firms; 3 ) establish what the trend toward a more innovative HRM model is; 4) analyse the determinants of in progress HRM system in the firm; and 5) characterise the companies that are most committed to these transformations.

We formulate three research hypotheses. Firstly, evidence has been found that the total effect of HRM practices is greater than the sum of the individual practices themselves on research based on a system's approach. Based on the relationship between different individual HRM practices, it is hypothesised:

Hypothesis 1: HRM practices operate as a system where they are mutually reinforcing.

Secondly, we will argue that external and internal firm that are conducive to the adoption of in progress HRM system may be expected to be found. It is hypothesised:

Hypothesis 2: Firm structure, new forms of work organisation, IT use level, interaction with international suppliers, collaboration networks for innovation, and business efficiency, are determinants in the adoption of an in progress system of HRM.

Finally, we will observe the link between in progress HRM system and the firm's characteristics which the literature has considered to be decisive for organisational innovation performance $[15,39,44]$ : firm size, sector affiliation, business group membership, performance in international markets, networks for innovation collaboration, strategy, culture, labour flexibility, IT and new forms of work organisation. This analysis will allow us to contrast the third hypothesis:

Hypothesis 3: Firms that adopt in progress HRM system: 1) are more internationalised and show greater ability to adapt to the changing environment, to innovate and to collaborate; 2) focuses product/service differentiation strategy enhancing quality; 3) apply a greater degree of new forms of work organization; 4) have more technological equipment and use IT more intensively; and 5) invest more in training their employees, than firms with non-HRM system developed.

In light of afore mentioned approach, we propose and test a conceptual model (depicted in Figure 1).

\section{Research Design and Data Collection}

\subsection{Sample and Questionnaire}

The data used in the empirical analysis was collected in the research project The Network Firm: ICTs, Productivity and Competitiveness in Catalan Firms [45]. The questionnaire included questions on the incidence of IT use in the transformation of value chain and firm performance. The survey was based on a representative sample of 2038 firms (with a margin of error of $+/-2.2$ percent) stratified by activity sector (collected according to OECD 2002 technology and knowledge-intensive sectors) and firm size (number of employees) [46,47]. Sample firms were contacted through telephone calls to confirm a contact 


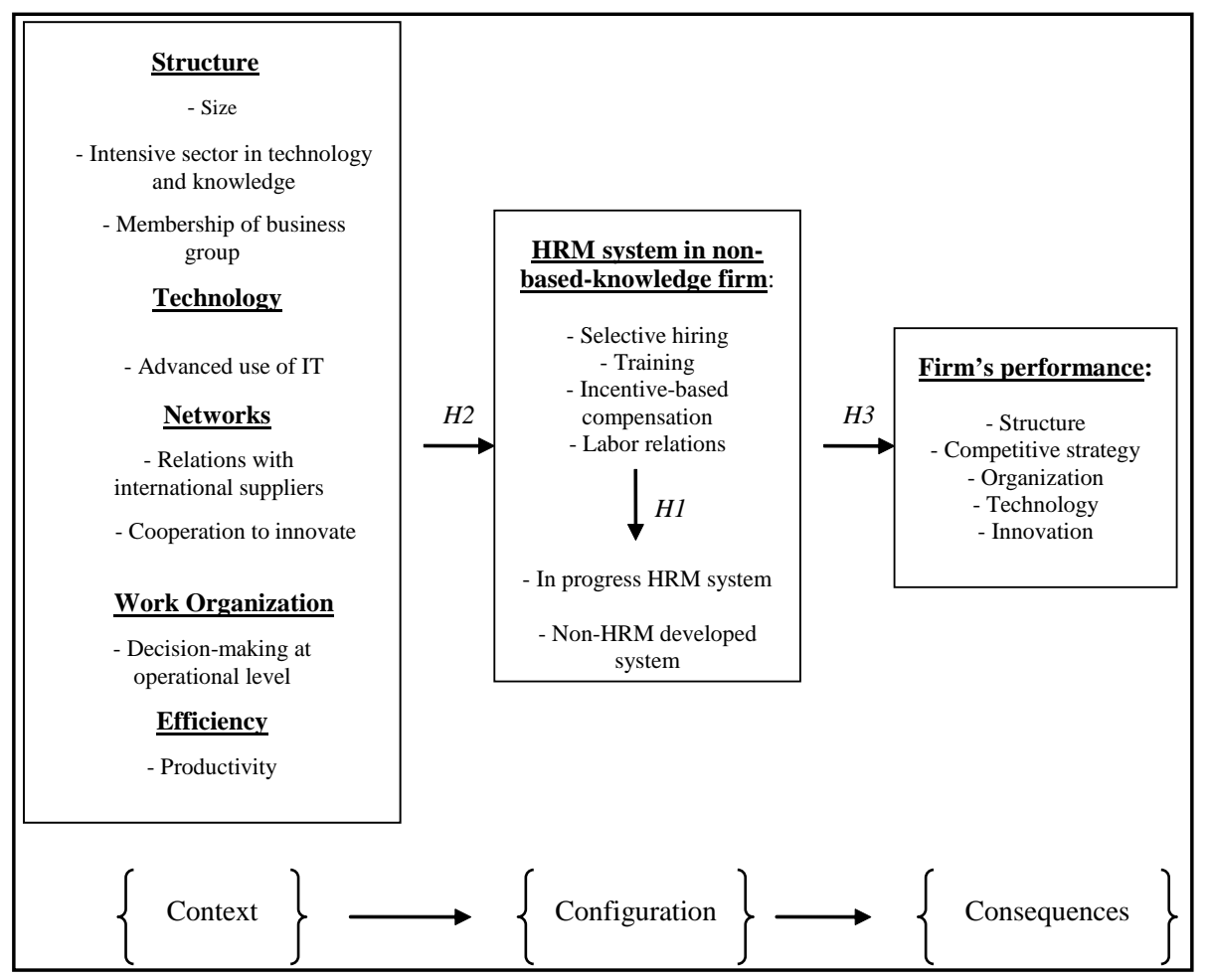

Figure 1. Conceptual model.

person in each firm, followed by survey questionnaires that were answered by managers by means of a face-toface, hour-long interview. The questionnaire consisted of 128 items and was completed with economic and financial information available from the Mercantile Registry of Spain, obtained by means of SABI (Iberian Balance Sheet Analysis System) software. The data set provides three types of data: 1) information about the firm's structure; 2) information about disposition and use of information technologies; and 3) information about elements of value chain. The study takes a cross-sectional approach. Follow-up data collection took place between January and May 2003. A careful examination of the data of these 2,038 firms led to the exclusion of 520 cases with contradictory or non-plausible answers; 1518 valid answers remained which were used for this analysis. Therefore, we re-weighted the reduced sample of firms based on a factor which gives each company the real weight it should have according to its size.

\subsection{Measures and Procedures}

Table 1 illustrates the survey items which serve as the basis for collecting data pertaining to HRM practices. The selection processes should be based on the ability of the employees to do their job. The workforce should be recruited with the necessary skills, expertise and qualifications to deliver organizational objectives and with the ability to contribute positively to the values and aims of the organization [48]. So selective hiring has been assessed through the educational level of managers and non-managers and the employees' most valued attributes by the business owner. To do so, we selected four variables: 1) highest education level achieved in managers: university level; 2) highest education level achieved in non-managers: university level; 3) attributes most valued in managers (values: leadership, and initiative or innovation ability $=1$; efficiency and productivity, work capacity or technical knowledge $=0$ ); and 4 ) attributes most valued in non-managers (values: initiative, innovation ability, work capacity or technical knowledge $=1$; efficiency and productivity or experience $=0$ ).

The second group of variables is related to training. Training programmes would show the employees and managers how the entire knowledge management framework is linked to the firm's strategy [49]. Therefore, we include two variables to approximate the share of managers and employees receiving job-related training: 1) internal and/or external training courses; 2) continuous and/or customised in training, initiated or supported by the firm.

From the perspective of labour relations, there is evidence that employment security may be seen as useful for employees to feel more identified with the firm. We approximate job security through types of contracts (values: indefinite contract $=1$; temporary contracts $=0$ ).

Another group of variables refers to compensation, linked to the employee and organisation performance 
Table 1. Human Resources Management (HRM) practices definition.

\begin{tabular}{|c|c|c|c|}
\hline Sets of practices & Variables in each set & Description of the variables & Values \\
\hline \multirow[t]{4}{*}{ Selective hiring } & EDMAN & Most frequently finished level of studies among managers: University level & Dichotomic $(0,1)$ \\
\hline & EDNONMAN & $\begin{array}{l}\text { Most frequently finished level of studies among non-management } \\
\text { employees: University level }\end{array}$ & Dichotomic $(0,1)$ \\
\hline & ATTMAN & $\begin{array}{l}\text { Most valued attributes for managers: Experience, leadership, } \\
\text { and initiative and innovation ability }\end{array}$ & Dichotomic $(0,1)$ \\
\hline & ATTNONMAN & $\begin{array}{l}\text { Most valued attributes for non-managerial employees: Initiative } \\
\text { and innovation ability, work capacity, and technical knowledge }\end{array}$ & Dichotomic $(0,1)$ \\
\hline \multirow[t]{2}{*}{ Training } & CTMAN & $\begin{array}{c}\text { Continuous and/or in company training for managers paid for } \\
\text { by the firm }\end{array}$ & Dichotomic $(0,1)$ \\
\hline & CTNONMAN & $\begin{array}{l}\text { tinuous and/or in company training for non-managerial employees } \\
\text { paid by the firm }\end{array}$ & D ichotomic $(0,1)$ \\
\hline \multirow[t]{3}{*}{$\begin{array}{l}\text { Incentive-based } \\
\text { compensation }\end{array}$} & REMMAN & $\begin{array}{l}\text { Type of remuneration: mixed, profit sharing, stock options, } \\
\text { bonuses or deferred compensation for managers }\end{array}$ & Dichotomic $(0,1)$ \\
\hline & REMNONMAN & $\begin{array}{l}\text { Type of remuneration: mixed, profit sharing, stock options, } \\
\text { bonuses or deferred compensation for non-managerial employees }\end{array}$ & Dichotomic $(0,1)$ \\
\hline & SALHR & Amount of above-average remuneration & Dichotomic $(0,1)$ \\
\hline Industrial relations & CONST & Type of contracting: indefinite contract & Dichotomic $(0,1)$ \\
\hline
\end{tabular}

compensation, as a means to retain workers. We use two variables that measure the extent to which the compensation is mixed-fixed and variable-and the extent to which the company offers incentives to its managers and employees related to this performance (profit sharing, stock options, bonuses or deferred compensation: pension plans, life insurance and others). Finally, there is evidence supporting the turnover effects of pay level at firm level [19]. According to the literature, paying above-market rate pay enables companies to attract and retain skilled employees. Thus, we include pay level in our analysis as a potentially important contributor to outcomes of interest to this study (average remuneration paid by Catalan firms is 18,436 Euros gross annually).

From the data (Table 2), an important distinction can be observed between managerial and non-managerial employees. Managers with a university level of education account for $55.7 \%$ of posts in firms while it is $21.4 \%$ for non-managers, suggesting than managers have received more formal education. Secondly, we see relevant statistical differences regarding the values that are most important to its employees. Only a quarter of the analyzed firms consider experience, leadership, initiative and capacity for innovation to be the values managers must primarily contribute. If we mean non-managerial workers, a very low percentage $(17.4 \%)$ consider initiative and capacity for innovation, work capacity and technical knowledge of greater relevance than other attributes. Thirdly, it is worth pointing out that a considerable percentage of firms (around 40\%) offer training for their professional development. Moreover, we observed that the efforts made by the firm to put forward continual onthe-job training are comparable for managerial and nonmanagerial employees, although the latter's need for training is much greater. In fourth place, it is observed that the indefinite contract is the principal contractual type in Catalonia's private productive network (68.1\%). Fifth, we observe a relevant presence of the variable form of remuneration for managers (63.6\%), which contrasts with the more modest implementation of these types of formulas for those who are not managers (21.5\%). Lastly, we corroborated that in little less than a third of analyzed firms (26.4\%) there is an average salary greater than Catalan average.

\section{Factor and Cluster Analysis}

Although the implementation of new HRM practices is not equal in the Catalan firm, we observe several internal complementarities that suggest the existence of an overall system of innovative HRM practices. Table 3 , which shows the means for the components and their correlations, confirms that several elements in the matrix have a very positive (coefficients over 0.30 ) and significant correlation.

Factor analysis is used to assess item correlations and identify common relationships between similar items, allowing the items to be categorized into various themes or factors. Analysis of the correlation matrix: KMO (0.573) and Bartlett's test of sphericity $(p=0.000)$ suggested that the correlation matrix was factorable. Data reduction was undertaken by principal components analysis using the Varimax option to identify possible underlying dimensions of HRM practices.

From the analysis, five factors emerged that explained 66.9 per cent of total variance (Table 4). Five factors were labelled: 1) Flexible remuneration; 2) Job training; 3) Qualifications; 4) Employment security; and 5) Mana- 
Table 2. Practices of HRM adopted by frequency.

\begin{tabular}{|c|c|c|c|}
\hline & & & Valid \\
\hline & & Frequency & percentage \\
\hline \multirow[t]{2}{*}{ EDMAN } & Most frequently finished level of studies among managers: university level & 845 & 55.7 \\
\hline & Secondary/primary level/no studies among managers & 673 & 44.3 \\
\hline \multirow[t]{2}{*}{ EDNONMAN } & Most frequently finished level of studies among non-management employees: university level & 325 & 21.4 \\
\hline & Secondary/primary level/no studies in non-managerial workers & 1193 & 78.6 \\
\hline \multirow[t]{2}{*}{ ATTMAN } & Most valued attributes for managers: Experience, leadership, and initiative and innovation ability & 416 & 27,4 \\
\hline & Previous attributes not mentioned in the first place & 1102 & 72.6 \\
\hline \multirow[t]{2}{*}{ ATTNONMAN } & $\begin{array}{l}\text { Most valued attributes for non-managerial employees: Initiative and innovation ability, } \\
\text { work capacity, and technical knowledge }\end{array}$ & 264 & 17.4 \\
\hline & Previous attributes not mentioned in the first place & 1254 & 82.6 \\
\hline \multirow[t]{2}{*}{ CTMAN } & Continuous and/or in company training for managers paid by the firm & 599 & 39.5 \\
\hline & No additional training for management & 917 & 60.5 \\
\hline \multirow[t]{2}{*}{ CTNONMAN } & Continuous and/or in company training for non-managerial employees paid by the firm & 614 & 40.8 \\
\hline & No additional training for non-management & 890 & 59.2 \\
\hline \multirow[t]{2}{*}{ REMMAN } & $\begin{array}{c}\text { Type of remuneration: mixed, profit sharing, stock options, bonuses or deferred compensation for } \\
\text { managers }\end{array}$ & 966 & 63.6 \\
\hline & Fixed remuneration & 552 & 36.4 \\
\hline \multirow[t]{2}{*}{$\begin{array}{l}\text { REMNON- } \\
\text { MAN }\end{array}$} & $\begin{array}{c}\text { Type of remuneration: mixed, profit sharing, stock options, bonuses or deferred compensation for } \\
\text { non-managerial employees }\end{array}$ & 326 & 21.5 \\
\hline & Fixed remuneration & 1192 & 78.5 \\
\hline \multirow[t]{2}{*}{ SALHR } & Amount of above-average remuneration & 400 & 35.2 \\
\hline & Salary less than or equal to the Catalan average & 735 & 64.8 \\
\hline \multirow[t]{2}{*}{ CONST } & Indefinite contract & 1034 & 68.1 \\
\hline & Other types of contracting & 484 & 31.9 \\
\hline
\end{tabular}

Table 3. Correlations and means.

\begin{tabular}{|c|c|c|c|c|c|c|c|c|c|c|}
\hline Variable & Mean & 1 & 2 & & & & & & & \\
\hline EDMAN & 0.551 & & & & & & & & & \\
\hline EDNONMAN & 0.218 & $0.282^{* *}$ & & & & & & & & \\
\hline ATTMAN & 0.265 & $-0.063^{*}$ & $-0.131^{* *}$ & & & & & & & \\
\hline ATTNONMAN & 0.170 & $0.109^{* *}$ & 0.024 & $0.077^{* * *}$ & & & & & & \\
\hline CTMAN & 0.393 & -0.010 & 0.012 & $0.045^{*}$ & 0.012 & & & & & \\
\hline CTNONMAN & 0.421 & $0.123^{* *}$ & 0.021 & $0.044^{*}$ & $0.049^{* *}$ & $0.432^{* * *}$ & & & & \\
\hline CONST & 0.668 & $-0.070^{*}$ & $0.089^{* * *}$ & -0.035 & $0.055^{* *}$ & 0.037 & 0.037 & & & \\
\hline REMMAN & 0.646 & $0.161^{* * *}$ & $0.181^{* * *}$ & 0.022 & $0.079^{* * *}$ & $0.179^{* * *}$ & $0.132^{* * *}$ & $-0.117^{* * *}$ & & \\
\hline REMNONMAN & 0.222 & $0.071^{* * *}$ & $0.184^{* * *}$ & $-0.078^{* * *}$ & $0.107^{* * *}$ & $0.148^{* * *}$ & $0.212^{* * *}$ & $0.054^{* *}$ & $0.396^{* * *}$ & \\
\hline SALHR & 0.345 & $0.134^{* * *}$ & $0.219^{* * *}$ & 0.010 & $-0.058^{* *}$ & $-0.054^{* *}$ & -0.016 & $0.083^{* * *}$ & $0.154^{* * *}$ & $0.118^{* * * *}$ \\
\hline
\end{tabular}

Note: ${ }^{* * *} \mathrm{p}<0.01 ;{ }^{* *} \mathrm{p}<0.05 ;{ }^{*} \mathrm{p}<0.1$.

gerial Competences.

Our aim in the next stage of data analysis was to identify distinct, yet homogeneous, groups of firms based on the level of HRM practices they adopt. A Non Hierarchical Cluster Analysis of K-means was applied. ANOVA test results showed that the means of contextual variables differ significantly across clusters. The associated Chi-square test allowed us to attribute statistical significance to the differences obtained. Overall analysis of the data permitted us to obtain an indicator for in progress HRM system. Non Hierarchical Cluster Analysis of
K-means was applied to the five factors obtained in the Factor Analysis plus a new variable HRMSUM, that indicates the number of innovative HRM practices (from 0 to 10) that each firm fulfils. Two clusters or behavioural patterns were found in Catalan firms, according to the degree to which firms adopted innovative HRM system (Table 5).

Cluster 1 is comprised by the firms that display or favour greater importance towards (managerial and nonmanagerial) employees' qualifications and the nonmanagerial workers' skills (0.606), that provide more 
Table 4. Varimax Rotated Factor Matrix of HRM practices.

\begin{tabular}{|c|c|c|c|c|c|c|}
\hline & Factor 1 & Factor 2 & Factor 3 & Factor 4 & Factor 5 & \\
\hline & $\begin{array}{c}\text { Flexible } \\
\text { remuneration }\end{array}$ & Job training & Qualifications & $\begin{array}{c}\text { Employment } \\
\text { security }\end{array}$ & $\begin{array}{c}\text { Managerial } \\
\text { competences }\end{array}$ & Commonalities \\
\hline EDMAN & 0.014 & 0,054 & 0,791 & -0.193 & -0.044 & 0.668 \\
\hline EDNONMAN & 0.264 & -0.062 & 0.641 & 0.246 & -0.173 & 0.575 \\
\hline ATTMAN & -0.047 & 0.060 & -0.131 & -0.052 & 0.911 & 0.856 \\
\hline ATTNONMAN & -0.273 & 0.204 & 0.450 & 0.065 & 0.239 & 0.634 \\
\hline CTMAN & 0.125 & 0.794 & -0.068 & 0.032 & 0.030 & 0.653 \\
\hline CTNONMAN & 0.084 & 0.801 & 0.101 & 0.028 & 0.031 & 0.661 \\
\hline REMMAN & 0.687 & 0.194 & 0.231 & -0.223 & 0.141 & 0.632 \\
\hline REMNONMAN & 0.676 & 0.281 & 0.093 & 0.096 & -0.107 & 0.565 \\
\hline CONST & -0.088 & 0.101 & -0.046 & 0.901 & -0.058 & 0.836 \\
\hline SALHR & 0.432 & -0.280 & 0.322 & 0.380 & 0.317 & 0.614 \\
\hline \% variance explained & 19.316 & 14.400 & 11.917 & 11.106 & 10.195 & \\
\hline
\end{tabular}

Notes: Rotated components matrix; Sampling method: factor analysis by main components; Rotation method: Varimax with Kaiser normalisation; convergence in 11 iterations.

Table 5. In progress HRM system in Catalan firms. Results of k-means (quick cluster) analysis

\begin{tabular}{ccc}
\hline & Cluster 1 & Cluster 2 \\
\hline Flexible remuneration & $\mathrm{n}=571$ & $\mathrm{n}=947$ \\
Job training & 0.518 & -0.312 \\
Qualifications & 0.532 & -0.321 \\
Employment security & 0.606 & -0.366 \\
Managerial competences & 0.328 & -0.198 \\
HRMSUM & 0.324 & -0.195 \\
\hline
\end{tabular}

Notes: Method of analysis: non-hierarchical cluster, final cluster centroids.

extensive professional and on-the-job training in terms of number of employees involved (0.532), and that have established mechanisms for flexible remuneration (0.518). Additionally, they are unlike the second group in terms of contractual stability (0.328) and the relevance given to new managerial competences (0.324). It is represented by firms that adopt in progress HRM systems. Cluster 2 is characterised by HRM practices completely different from the previous ones and where all the factors identified are negative. It is represented by firms that adopt much more traditional HRM practices or do not adopt any at all (non-HRM developed system).

Thus, and depending on the HRM systems adoption, we can characterise the Catalan firm in two clusters: 1 ) cluster 1, that uses all five of the HRM practices, can be considered to be the type of firm that uses the in progress system of HRM (37.6\% of the firms); and 2) cluster 2 that contains groups of companies, most of Catalonia's private productive network ( $62.4 \%$ of the firms), that can be considered to use much more traditional practices or use none of the in progress HRM systems. The analysis of HRMSUM variable allows us to explore the distribution of the conditions fulfilled in each of the two identified groups of firms. The first group is where the greater number of initial conditions are met (from 5 to 10, with an average of 5.87); while in the second group, the firms only meet between 0 and 4 of the initial conditions (an average of 2.71). In terms of sections, $77.8 \%$ of the firms in group 1 meet 5 or 6 conditions, while only $4.3 \%$ of the firms carry out between 8 and 10 of the in progress HRM practices.

\section{Estimation}

With the aim of estimating the overall effect of individual variables on the adoption of in progress HRM system, we applied a binomial logit model. The parameters for the binary logistic regression model are described in equation:

$$
\begin{aligned}
\text { IPHRMS }_{\mathrm{i}} & =\beta_{0}+\beta_{1} * \mathrm{SIZE}_{\mathrm{i}}+\beta_{2} * \mathrm{STPROP}_{\mathrm{i}} \\
& +\beta_{3} * \mathrm{SECT}_{\mathrm{i}}+\beta_{4} * \mathrm{ADVIT}_{\mathrm{i}}+\beta_{5} * \mathrm{INTSUP}_{\mathrm{i}} \\
& +\beta_{6} * \mathrm{COOPNET}_{\mathrm{i}}+\beta_{7} * \mathrm{DE}
\end{aligned}
$$

where, IPHRMS $=$ a dichotomous dependent variable $(1$ 
if in progress HRM system adoption takes place, 0 otherwise); $\beta=$ parameters to be estimated; and $\varepsilon_{\mathrm{i}}=$ error term of the model. The interpretation of standardized regression coefficients determines the probability that the independent variables represented in the model explain the adoption of in progress HRM system in the Catalan firms.

Regarding the independent variables, we contemplated a first group of business structure variables: a) size (SIZE); b) structure of the property (STPROP); and c) the sector of activity (SECT). We shall presume that large firms, which form part of a business group and whose activity is intensive in technology and knowledge use, are more likely to adopt in progress HRM system. The SIZE variable takes the value of 1 when the firm has more than 20 employees; and the value of 0 when it has fewer than 20 employees. The STPROP variable takes the value of 1 if the firm forms part of a group of companies; and the value of 0 if it does not belong to a business group. The SECT variable takes the value of 1 when the firm belongs to the sectors in the sample identified as intensive in the use of technology or knowledge: information industry, high tech industry and knowledge-intensive services; and the value of 0 when it is located in low or medium tech industry and in less knowledge-intensive services.

From the technological perspective, it has been proven that more intensive use of information technology is decisive in the adoption of more innovative HRM system, that they favour the workers' skills level and their involvement with the firm. With the aim of measuring this effect, we considered the ADVIT variable, which takes the value of 1 when IT use is advanced and the value of 0 when use is low or mid-level. To determine advanced IT use, we generated an indicator for IT use which gathers the sufficiency of use in five elements of value chain in business activity: 1) production; 2) supplies and distribution; 3) marketing; 4) organisation and basic human resources (accounting and invoicing, payroll payment and internal communication); and 5) organisation and complex human resources (data management and/or information exploitation, information systems for management and integrated management systems). This sufficiency, which is collected through the arrangement of digital technology systems in each of the five elements of value chain, determines the three levels of the indicator: a) low use of IT, when the firm does not have technological systems in any or has in just one, of the five defined elements of value; $b$ ) mid-level use of IT, when the firm has technological systems for two or three of the five defined elements of value; and c) advanced use of IT, when the firm has technological systems in four or five of the defined elements of value.

Another set of independent variables is determined by the firm's strategic and organisational resources. Regard- ing strategy, we considered a quality management variable. Quality management means greater sophistication in the utilisation of productive processes and a greater emphasis on employee's development, thus quality management should be linked to a more sophisticated level of HRM. To measure this effect, we used a variable that measures the implementation of quality certification in the firm (QUAL), and which takes the value of 1, when the firm has an accredited system to guarantee quality; and the value of 0 if it does not.

In terms of workplace practices, we incorporated autonomy and decision-making capacity when workers carrying out their labour tasks, as well as labour control and supervision systems. We shall presume that the movement of the decision-making process towards operational level is linked with HRM practices that involve workers more. The DECPROC variable, takes the value of 1 when the firm's workers at operational level make decisions at operational level, and the value of 0 when there is no delegation of responsibility towards them. Additionally, the management by objectives, instead of the traditional hierarchical structure, involves establishing mechanisms for arranging HRM activities. In this regard, we considered the variable of control and supervision by objectives and results (MANOBJ), which takes its values depending on their application: yes, value of 1 ; and no, value of 0 .

HRM has also been involved in the nature of existing labour relations in the firm, and particularly in the role played by trade unions. Trade unions should be interested in those organisational changes which give the workers a greater presence and larger role in internal decisionmaking. Nonetheless, they can also consider the incorporation of more flexible systems of HRM as a threat to employment security. To measure the trade unions' capacity regarding the generation of innovation in HRM, the variable TRADUNI takes the value of 1 and indicates the presence of trade unions in the firm; and the value of 0 when there are not.

The literature also confirms that ties outside the company are very relevant for innovation. In this regard, businesses that have established cooperation networks with other companies or institutions should be more willing to facilitate internal innovation through more innovative HRM systems. The COOPNET variable takes the value of 1 when the firm's cooperation (present or past) with other firms and/or institutions has led to innovation. If the firm does not or has not cooperated in innovation with other firms and institutions, this variable takes the value of 0 . Additionally, we included a variable that measures the firm's interaction with international suppliers (INTSUP). This variable takes the value of 1 when the firm has suppliers that are from the European Union or the rest of the world; and the value of 0 , in the opposite 
case (Catalonia and the rest of Spain).

Lastly, and as we have pointed out, other research finds a significant correlation between in progress HRM systems and several business efficiency measures. We presuppose that efficient businesses are characterised by a greater concern for their competitive advantage in general and the innovative management of their human resources in particular. Based on the sales quotient per worker in the firm, we generate the SALEWKR variable, which takes the value of 1 when the average is greater than the Catalan average (135.6 thousand Euros) and takes the value of 0 when it is less than or equal to the Catalan average.

After running the model and applying the Wald Statistic and the Likelihood-Ratio Statistic, the TRADUNI, QUAL and MANOBJ variables were not statistically significant ( $p$ values $>0.10$ ) and therefore they were disesteemed or rejected. To increase the goodness of fit and explanatory power, they were eliminated from the model. The estimated coefficients are presented in Table 6.

The model correctly classified $69.1 \%$ of firms (75.8\% of those that do not use in progress HRM system and $61.5 \%$ of those that use in progress HRM system). The Nagelkerke's $\mathrm{R}^{2}$ equals to 0.238 . The improvement in the likelihood function is significant (from 1381.9 to 1245.1). It accepts the goodness-of-fit of the predictive capacity and the variables as a whole have an outstanding explanatory power (Hosmer-Lemeshow test $=0.957$; $\mathrm{p}=$ 0000).

From the estimation of the model, it is found that all the variables included have a very significant explanatory power regarding the decision to incorporate in progress HRM system in the Catalan firm ( $p<0.01)$. The relationships of influence found have a plus sign. It is observed that the structural variables of the firm (size, technology and knowledge intensive sector, and membership in a business group), relationship with international suppliers and firms, networks for cooperation with other institutions and firms, decentralisation in decision making and business efficiency play a positive and significant role in the probability of the adoption of in progress HRM system for the non-based-knowledge case of Catalan firms.

\section{Association Analysis}

Finally, we carried out statistical analysis of the relationships between the in progress HRM system and several measurements of structure and firm performance. This analysis can be summarised on the basis of the following results (Table 7):

1) Structure of the firm. In progress HRM system is evidenced, in percentages that are higher than expected, in: a) the services sector; b) firms that form part of a business group; c) firms which have foreign capital, primarily from the European Union; d) the most interna- tionalised firms; e) firms with a differential presence of clients and suppliers from outside Catalonia (Spain, the European Union, and the rest of the world); and f) firms with a high degree of collaboration with their competitors.

2) Competitive strategy. In progress HRM system is demonstrated, in a greater percentage, in the firms that: a) opt for a strategy of product differentiation or specialised service; and b) have carried out improvements in their productive process through quality control of products or services.

3) Work organisation practices. Firms with in progress HRM system opt, in a greater percentage, for: a) delegation of authority in decision making; b) using flexible and adaptable work teams; c) a greater flow of communication among workers; d) coordination systems based on work supervision by objectives; and e) a significantly greater percentage of externalised or subcontracted operations.

4) Technological and innovation perspective. Catalan firms with in progress HRM system have at their disposal, in a greater percentage than those firms with traditional system: a) more digital technological equipment; b) a better level of internet equipment; c) more advanced IT use; d) a dynamic of greater innovation in the productive process through IT; and e) superior development of organisational innovation.

In summary, firms that adopt in progress HRM systems show a structure of value chain and a business performance more advanced than firms that adopt more traditional HRM systems.

\section{Contributions and Future Research}

In this research paper, we have contemplated on in progress human resources management (HRM) system, its characteristics and determinants, for the specific case of the non-based-knowledge Catalan firms. On the basis of the four basic dimensions of HRM (selection, training, hiring and remuneration), and using survey data on 1518 Catalan firms (in Spain, with capital in Barcelona), we obtained five factors: flexible remuneration, job training, qualifications, employment security, and managerial competences, which have allowed us to identify a system of in progress HRM practices.

The empirical evidence obtained demonstrates that most of Catalan firms (about two thirds) have traditional forms of HRM (non-HRM developed system), and that those firms incorporating in progress system of HRM practices (slightly more than a third of the total) have a considerably differentiated profile. Medium-sized and large firms (more than 20 workers), that form part of a business group, belonging to a knowledge-intensive sector, with advanced IT use, establish collaboration networks with firms and institutions in order to innovate, 
Table 6. Determinants for the adoption of in progress HRM system.

\begin{tabular}{cccccc}
\hline & Estimated coefficient & Standard error & Wald & Significance & Exp ( $\beta)$ \\
\hline SIZE & $\mathbf{0 . 4 5 3}$ & 0.152 & 8.817 & 0.003 & 1.572 \\
STPROP & 0.758 & 0.168 & 20.241 & 0.000 & 2.134 \\
SECT & 0.839 & 0.140 & 35.768 & 0.000 & 2.314 \\
ADVIT & 0.692 & 0.205 & 11.369 & 0.001 & 1.999 \\
INTSUP & 0.387 & 0.144 & 7.191 & 0.000 & 1.472 \\
COOPNET & 0.556 & 0.140 & 15.788 & 0.000 & 1.743 \\
DECPROC & 0.579 & 0.155 & 13.909 & 0.000 & 1.785 \\
SALEWKR & 0.568 & 0.160 & 12.540 & 0.000 & 1.765 \\
Constant & -1.715 & 0.152 & 127.552 & 0.000 & 0.180 \\
\hline
\end{tabular}

Notes: Method of regression: binomial logit analysis; dependent variable: In Progress HRM System (value 1, adopted; value 0, not adopted); standardised coefficients. Statistics: -2 Log-likelihood = 1.245.113; $\mathrm{R}^{2}$ Cox-Snell = 0.178; $\mathrm{R}^{2}$ Nagelkerke $=0.238 ;$ Hosmer-Lemeshow test $=0.957 ; \mathrm{p}=0.000$.

Table 7. In progress HRM system and structure and performance of Catalan firms.

\begin{tabular}{|c|c|c|c|}
\hline & In progress HRM system & Non-HRM developed system & Significance \\
\hline Sector of activity & & & 0.000 \\
\hline Information industry & 5.0 & 9.0 & \\
\hline Mid tech industry & 1.2 & 4.4 & \\
\hline High tech industry & 2.6 & 1.4 & \\
\hline Knowledge intensive services & 24.9 & 19.7 & \\
\hline \multicolumn{4}{|l|}{ Property structure } \\
\hline Forms part of a business group & 19.2 & 7.5 & 0.000 \\
\hline \multicolumn{4}{|l|}{ Internationalisation of sales and origin of capital } \\
\hline Percentage of sales in Catalonia & 73.3 & 79.9 & 0.001 \\
\hline Percentage of sales in the EU & 6.7 & 4.2 & 0.006 \\
\hline Percentage of sales in the rest of the world & 4.2 & 1.2 & 0.000 \\
\hline \% of Catalan capital & 92.3 & 96.8 & 0.000 \\
\hline$\%$ of capital from the rest of Spain & 0.3 & 2.4 & 0.000 \\
\hline \% of capital from the EU & 6.9 & 0.7 & 0.000 \\
\hline$\%$ of capital from the rest of the world & 0.5 & 0.0 & 0.070 \\
\hline \multicolumn{4}{|l|}{ Stakeholders to the firm } \\
\hline Suppliers from Spain & 70.0 & 61.9 & 0.000 \\
\hline Suppliers from the EU & 52.5 & 27.5 & 0.000 \\
\hline Suppliers from the rest of the world & 29.5 & 15.5 & 0.000 \\
\hline The firm carries out activities with the competitors & 40.4 & 19.6 & 0.000 \\
\hline \multicolumn{4}{|l|}{ Competitive strategy } \\
\hline Competitive strategy of the firm based on: & & & 0.000 \\
\hline - Quality control of products and services & 92.2 & 80.3 & \\
\hline \multicolumn{4}{|l|}{ Strategic redesigning of objectives } \\
\hline - Due to changes in demand & 71.6 & 62.3 & 0.001 \\
\hline - Due to improvements in the offer & 63.6 & 54.0 & 0.001 \\
\hline - To adapt to changes in environment & 58.2 & 46.2 & 0.000 \\
\hline \multicolumn{4}{|l|}{ Work organisation practices } \\
\hline - Organisational innovations in the last two years & 46.4 & 32.5 & 0.000 \\
\hline - Workers at operational level make decisions & 37.8 & 33.1 & 0.076 \\
\hline
\end{tabular}




\begin{tabular}{|c|c|c|c|}
\hline \multicolumn{4}{|c|}{ Continued } \\
\hline - Existence of flexible and adaptable work teams & 53.3 & 44.8 & 0.003 \\
\hline - Workers can share and exchange information & 97.6 & 95.1 & 0.025 \\
\hline - Supervision by objectives & 71.6 & 62.9 & 0.002 \\
\hline \multicolumn{4}{|l|}{ ICT equipments and uses } \\
\hline Webpage & 57.6 & 40.9 & 0.000 \\
\hline E-mail & 96.7 & 85.0 & 0.000 \\
\hline Intranet (LAN/WAN) & 67.6 & 52.3 & 0.000 \\
\hline Internet equipment: & & & 0.000 \\
\hline - Very low (no connection) & 3.2 & 7.5 & \\
\hline - Low (connection with narrowband) & 40.8 & 52.9 & \\
\hline - Normal (connection with narrowband and webpage) & 52.1 & 37.4 & \\
\hline - Advanced (connection with broadband and webpage) & 3.9 & 2.2 & \\
\hline Payroll payment systems by means of IT & 45.7 & 22.5 & 0.000 \\
\hline Internal communications systems & 21.3 & 12.3 & 0.000 \\
\hline Information management systems & 16.6 & 6.2 & 0.000 \\
\hline Executive information systems (EIS) & 11.6 & 4.0 & 0.000 \\
\hline Integrated management systems (ERP) & 11.1 & 1.7 & 0.000 \\
\hline Utilisation of IT in the covering vacant positions & 22.7 & 16.3 & 0.000 \\
\hline Level of IT use: & & & 0.000 \\
\hline - Low IT use & 55.7 & 81.1 & \\
\hline - Medium IT use & 39.3 & 16.7 & \\
\hline - Advanced IT use & 5.0 & 2.1 & \\
\hline \multicolumn{4}{|l|}{ Innovation in IT use } \\
\hline IT innovation in the last two years & 59.7 & 49.1 & 0.000 \\
\hline Process innovation based on IT & 47.4 & 34.9 & 0.000 \\
\hline
\end{tabular}

Notes: percentages of firms and chi-squared significance.

whose suppliers are geographically international, that favour more decentralised decision-making and are efficient are the firms with greater probability of incorporating in progress HRM system. Finally, using association analysis, we find that firms that adopt in progress HRM system 1) are more internationalised and show greater ability to adapt to the changing environment, to innovate and to collaborate; 2) focus on product/service differentiation strategy enhancing quality; 3) apply a greater degree of new forms of work organization; 4) have more technological equipment and use IT more intensively; and 5) invest more in training their employees, than firms with non-HRM system developed. In fact, firms that adopt in progress HRM systems show a structure of value chain and a business performance more advanced than firms that adopt more traditional HRM systems.

Despite the limitations of the research, particularly the lack of a time series and the restrictions imposed by the indicators and the methodologies used, the results obtained are consistent with other studies carried out at firm level, as well as in other regions and sectors $[15,50]$. However, the specific non-based-knowledge features of the overall productive system in Catalonia (very small firms, low intensity in technology and knowledge, with low levels of education, training and IT use, and serious problems of productivity and competitiveness) allow the results obtained to be extrapolated to other regions and groups of firms.

Everything seems to indicate that the processes of technological, strategic and organisational co-innovation combine with efficiency in the explanation for the adoption of in progress HRM systems. This process which, undoubtedly, generates sources of competitive advantage, is only valid for a small group of Catalan firms. It will be difficult to improve the competitive advantage of the remainder productive network without tackling new combinations in HRM, together with other new innovation processes. In this regard, in upcoming research we propose to tackle the analysis of the sources (technological, strategic, organisational and HRM-related) of firms efficiency.

\section{REFERENCES}

[1] M. Castells, "The Rise of the Network Society,” Blackwell, Oxford, 1996.

[2] M. Castells, "The Network Society. A Cross-cultural Perspective,” Edward Elgar, Cheltenham and Northampton, 2004. 
[3] M. Carnoy, "Sustaining the New Economy: Work, Family, and Community in the Information Age," Russell Sage Foundation/Harvard University Press, New York, 2000.

[4] R. M. Lindley, "Knowledge-based Economies: the European Employment Debate in a New Context," In: M.J. Rodrigues, Ed., The New Knowledge Economy in Europe. A Strategy for International Competitiveness and Social Cohesion, Edward Elgar, Cheltenham and Northampton, 2002, pp. 95-145.

[5] A. Pettigrew, R. Whittington, L. Melin, C. SanchezRunde, F. A. J. Van den Bosch, W. Ruigrok and T. Numagami, "Forms of Organising,” Sage, London, 2003.

[6] I. Svetlik and E. Stavrou-Costea, "Connecting Human Resources Management and Knowledge Management," International Journal of Manpower, Vol. 28, No. 3-4, 2007, pp. 197-206. http://dx.doi.org/10.1108/01437720710755209

[7] M. . Lengick-Hall and S. Moritz, "The Impact of e-HR on the Human Resource Management Function,” Journal of Labor Research, Vol. 24, No. 3, 2003, pp. 365-379. http://dx.doi.org/10.1007/s12122-003-1001-6

[8] H. J. M. Ruël, T. Bondarouk and J. C. Looise, "E-HRM: Innovation or Irritation. An Explorative Empirical Study in Five Large Companies on Web-based HRM," Management Review, Vol. 15, No. 3, 2004, pp. 364-381.

[9] S. Strohmeier, "Research in e-HRM: Review and Implications," Human Resource Management Review, Vol. 17, No. 1, 2007, pp. 19-37. http://dx.doi.org/10.1016/j.hrmr.2006.11.002

[10] J. Baron and D. M. Kreeps, "Strategic Human Resources," John Wiley, New York, 1999.

[11] M. Murphy, "Organisational Changes and Firm Performance,”OECD STI Working Papers No. 14, OECD, Paris, 2002. http://dx.doi.org/10.1787/615168153531

[12] J. Vilaseca-Requena, J. Torrent-Sellens and A. I. Jimenez-Zarco, "ICT Use in Marketing as Innovation Success Factor: Enhancing Cooperation in New Product Development Processes," European Journal of Innovation Management, Vol. 10, No. 2, 2007, pp. 268-288. http://dx.doi.org/10.1108/14601060710745297

[13] B.-A. Lundvall and P. Nielsen, "Knowledge Management and Innovation Performance," International Journal of Manpower, Vol. 28, No. 3-4, 2007, pp. 207-223. http://dx.doi.org/10.1108/01437720710755218

[14] K. Shaw, "By What Means Does Information Technology Affect Employment and Wages?” In: N. Greenan, Y. L'Horty and J. Mairesse, Eds., Productivity, Inequality, and the Digital Economy. A Transatlantic Perspective. MIT Press, Cambridge, 2002, pp. 229-267.

[15] N. J. Foss, "Strategy, Economic Organization, and the Knowledge Economy. The Coordination of Firms and Resources," Oxford University Press, Oxford and New York, 2005. http://dx.doi.org/10.1093/0199240647.001.0001

[16] D. L. Stone, E. F. Stone-Romero and K. Lukaszewski, "Factors Affecting the Acceptance and Effectiveness of Electronic Human Resource Systems," Human Resource
Management Review, Vol. 16, No. 2, 2006, pp. 229-244. http://dx.doi.org/10.1016/j.hrmr.2006.03.010

[17] P. Ficapal-Cusí, J. Torrent-Sellens and P. Curòs-Vilà, "Information Technology, Human Resources Management Systems and Firm Performance: An Empirical Analysis from Spain,” Journal of Systemics, Cybernetics and Informatics, Vol. 9, No. 2, 2011, pp. 32-38.

[18] J. Vilaseca-Requena and J. Torrent-Sellens, "ICTs and Transformations in Catalan Companies,” Innovation and Firm Development Centre, Government of Catalonia, Barcelona, 2004.

[19] M. A. Huselid, “The Impact of Human Resources Management Practices on Turnover, Productivity and Corporate Financial Performance," Academy of Management Journal, Vol. 38, No. 3, 1995, pp. 635-672. http://dx.doi.org/10.2307/256741

[20] C. Ichniowski, "Human Resources Management Systems and the Performance of U.S. Manufacturing Business," NBER Working Paper 3449, Cambridge, 1990.

[21] P. Osterman, "How Common Is Workplace Transformations and Who Adopts It?” Industrial and Labour Relations Review, Vol. 47, No. 2, 1994, pp. 173-187. http://dx.doi.org/10.2307/2524415

[22] T. Kochan and P. Osterman, "The Mutual Gains Enterprise,” Harvard Business School Press, Cambridge, 1994.

[23] E. Appelbaum, T. Bailey, P. Berg and A. L. Kallerberg, "Manufacturing Advantage. Why High-Performance Work Systems Pay Off?” In: E. Appelbaum and A. L. Kallerberg, Ed., Measuring the Components of a High- Performance Work System, Cornell University Press, Ithaca, 2000, pp. 208-254.

[24] E. Carayannis and J. Sagi, "New vs. Old Economy: Insights on Competitiveness in the global IT Industry," Technovation, Vol. 21, No. 8, 2001, pp. 501-514. http://dx.doi.org/10.1016/S0166-4972(00)00072-9

[25] J. Child and R. G. McGrath, “The Organizations Unfettered: Organizational Form in an Information-intensive Economy," Academy of Management Journal, Vol. 44, No. 6, 2001, pp. 1135-1149.

http://dx.doi.org/10.2307/3069393

[26] J. Gant, C. Ichniowski and K. Shaw, "Social Capital and Organizational Change in High-involvement and Traditional Work Organizations," Journal of Economics \& Management Strategy, Vol. 11, No. 2, 2002, pp. 289-328. http://dx.doi.org/10.1162/105864002317474576

[27] E. Lawler, S. A. Mohrman and G. E. Ledford, "Strategies for High Performance Organizations. The CEO Report: Employee Involvement, TQM and Reengineering Programs in Fortune 1000 Corporations,” Jossey-Bass, San Francisco, 1998.

[28] J. P. MacDuffie, "Human Resource Bundles and Manufacturing Performance: Organizational Logic and Flexible Production Systems in the World Auto Industry," Industrial and Labor Relations Review, Vol. 48, 1995, pp. $197-$ 221. http://dx.doi.org/10.2307/2524483

[29] J. Pfeffer, "New Directions for Organization Theory: Problems and Prospects," Oxford University Press, New York, 1997. 
[30] F. K. Pil and J. P. MacDuffie, "The Adoption of High-Involvement Work Practices,” Industrial Relations, Vol. 35, No. 3, 1996, pp. 423-455. http://dx.doi.org/10.1111/j.1468-232X.1996.tb00414.x

[31] C. Ichniowski, K. Shaw and G. Prennushi, "The Effects of Human Resources Management Practices on Productivity: A Study of Steel Finishing Lines,” American Economic Review, Vol. 87, No. 3, 1997, pp. 291-313.

[32] E. Brynjolfsson and L. M. Hitt, "Beyond Computation: Information Technology, Organizational Transformation, and Business Performance,” Journal of Economic Perspectives, Vol. 14, No. 4, 2000, pp. 23-48. http://dx.doi.org/10.1257/jep.14.4.23

[33] T. F. Bresnahan, E. Brynjolfsson and L. M. Hitt, "Information Technology, Workplace Organization and the Demand for Skilled Labor: A Firm-level Evidence," Quarterly Journal of Economics, Vol. 117, No. 1, 2002, pp. 339-376.

http://dx.doi.org/10.1162/003355302753399526

[34] A. P. Bartel, C. Ichniowski and K. Shaw, "The Strategic Investment in Information Technologies and New Human Resource Practices and their Effects on Productivity: An insider-Econometric Analysis,” National Bureau of Economic Research Summer Institute, Cambridge, 2004.

[35] S. E. Black and L. M. Lynch, "How to Compete: The Impact of Workplace Practices and Information Technology on Productivity," Review of Economics and Statistics, Vol. 83, No. 3, 2001, pp. 434-445. http://dx.doi.org/10.1162/00346530152480081

[36] S. E. Black and L. M. Lynch, "What's Driving the New Economy? The Benefits of Workplace Innovation," The Economic Journal, Vol. 114, No. 493, 2004, pp. F97-F116. http://dx.doi.org/10.1111/j.0013-0133.2004.00189.x

[37] E. Brynjolfsson and L. M. Hitt, "Computing Productivity: Firm-Level Evidence,” Review of Economics and Statistics, Vol. 85, No. 4, 2003, pp. 793-808. http://dx.doi.org/10.1162/003465303772815736

[38] S. Arvanitis, "Computerization, Workplace Organization, Skilled Labour and Firm Productivity: Evidence from the Swiss Business Sector," Economics of Innovation and New Technologies, Vol. 14, No. 4, 2005, pp. 225-249. http://dx.doi.org/10.1080/1043859042000226257

[39] N. Bloom, L. Garicano, R. Sadun and J. Van Reenen, "The Distinct Effects of Information Technology and Com- munication Technology on Firm Organization,” NBER Working Paper, No. 14975, Cambridge, 2009.

[40] N. Bloom, R. Sadun and J. Van Reenen, "The Organization of Firms across Countries,” NBER Working Paper, No. 15129, Cambridge, 2009.

[41] P. Osterman, "Work Reorganization in an Era of Restructuring: Trends in Diffusion and Effects on Employee Welfare," Industrial and Labour Relations Review, Vol. 53, No. 2, 2000, pp. 179-196. http://dx.doi.org/10.2307/2696072

[42] G. Boning, C. Ichniowski and K. Shaw, "Opportunity Counts: Teams and the Effectiveness of Production Incentives," NBER Working Paper, No. 8306, Cambridge, 2001.

[43] E. Caroli and J. Van Reenen, "Skill Biased Organizational Change? Evidence from a Panel of British and French Establishments," Quarterly Journal of Economics, Vol. 116, No. 4, 2001, pp. 1449-1492. http://dx.doi.org/10.1162/003355301753265624

[44] P. Osterman, "The Wage Effects of High Performance Work Organization in Manufacturing,” Industrial and Labour Relations Review, Vol. 59, No. 2, 2006, pp. 187-204.

[45] J. Torrent-Sellens and J. Vilaseca-Requena, "The Network Company in Catalonia: ICT, Productivity, Competitiveness, Wages and Returns in Catalonia's Firms," Open University of Catalonia (UOC), Barcelona.

http://www.uoc.edu/in3/pic/eng/network company.html.

[46] OECD, "OECD Information Technology Outlook. ICTs and the Information Economy,” OECD, Paris, 2002.

[47] OECD, "ICT and Economic Growth. Evidence from OECD Countries, Industries, and Firms,” OECD, Paris, 2003.

[48] Chartered Institute of Personnel and Development (CIPD), "Recruitment, Retention and Turnover 2007: Annual Survey Report,” CIPD, London, 2007.

[49] K. Kamoche and F. Mueller, "Human Resource Management and the Appropriation-Learning Perspective," $\mathrm{Hu}$ man Relations, Vol. 51, No. 8, 1998, pp. 1033-1060. http://dx.doi.org/10.1177/001872679805100803

[50] C. García-Olaverri, E. Huerta-Arribas and M. LarrazaKintana, "Human and Organizational Capital: Typologies among Spanish Firms," International Journal of Human Resource Management, Vol. 17, No. 2, 2006, pp. 316-330. http://dx.doi.org/10.1080/09585190500404788. 